\title{
ARABIC TEACHER CREATIVITY TOWARDS THE USE OF INFORMATION TECHNOLOGY IN DISTANCE LEARNING
}

\author{
Nabella Sabella ${ }^{1}$, Hasan $^{2}$, \\ Sekolah Tinggi Ilmu Quran (STIQ) Amuntai \\ ․ㅡabella1308@gmail.com, ${ }^{2}$ hasanbanjary@gmail.com
}

\begin{abstract}
The main problem in this study, along with the COVID-19 pandemic, which has plagued Indonesia for more than a year, has caused various problems and impacted various aspects of life, especially in education. To reduce the spread of COVID-19, the government enforces distance learning, which also impacts learning Arabic and requires teachers to develop creativity in learning. Using a qualitative field research method, this study aims to determine the creativity of Arabic language teachers in utilizing information technology for distance learning during the covid-19 pandemic. As for some of the media used, such as. Create video content, take advantage of social media, use video conferencing applications such as Zoom and Google Meet, to take advantage of educational website services in the form of Google Classroom and Wordwall games. Based on the results of the analysis conducted by the researchers, this study proved that there are various kinds of teacher creativity in learning Arabic online, such as interactive multimedia, quizzes with google forms, word wall games, and so on. Second, eliminating student learning boredom by developing teacher creativity based on information technology. Third, it is still necessary to conduct information technology-based creativity development training, especially in learning Arabic, because not all Arabic language teachers can develop information technology-based teaching skills. This study proved that there are various kinds of teacher creativity in learning Arabic online, such as interactive multimedia, quizzes with google forms, word wall games. Second, eliminating student learning boredom by developing teacher creativity based on information technology.
\end{abstract}

Keywords: Creativity, Arabic Teacher, Distance Learning, Information Technology.

\section{PRELIMINARY}

In December 2019 the world for the first time received news about cases similar to pneumonia, these cases were caused by a virus, which we know as COVID-19, this virus has a higher spread characteristic. This case was first discovered in Wuhan, China. The first COVID-19 was reported in Indonesia on March 2, 2020, with two cases. As of March 30, 2020, there were 693,224 cases and 33,106 deaths worldwide. ${ }^{1}$

The COVID-19 pandemic has had a very significant impact on the entire world's population. All segments of human life on earth are disrupted, without exception education. Manycountries have decided to close schools, colleges, and universities, including Indonesia. ${ }^{2}$ The health crisis caused by the COVID-19 outbreak has spearheaded simultaneous online learning. The online learning tsunami has occurred almost all over the world during the COVID-19

${ }^{1}$ Adityo Susilo et al., "Coronavirus Disease 2019: Tinjauan Literatur Terkini," Jurnal Penyakit Dalam Indonesia 7, no. 1 (April 1, 2020): 45, https://doi.org/10.7454/jpdi.v7i1.415.

${ }^{2}$ Rizqon H Syah, "Dampak Covid-19 pada Pendidikan di Indonesia: Sekolah, Keterampilan, dan Proses Pembelajaran," SALAM: Jurnal Sosial dan Budaya Syar-i 7, no. 5 (April 14, 2020), https://doi.org/10.15408/sjsbs.v7i5.15314.

Al Qalam: Jurnal Ilmiah Keagamaan dan Kemasyarakatan Vol. 16, No. 2

Maret - April 2022 
Nabella Sabella, Hasan : Arabic Teacher Creativity Towards The Use of Information Technology In Distance Learning

pandemic. Teachers and educators as an important element in teaching are required to make an unprecedented massive migration from traditional face-to-face education to online education or distance education. This is supported by technological developments that are not limited to the current industrial revolution 4.0. Online learning is effective for carrying out learning even though educators and students are in different places. ${ }^{3}$

After the pandemic, the Indonesian government has issued a new policy regarding education regulations, namely the implementation of PJJ. The term PJJ existed in Indonesian legislation long before the outbreak of the COVID-19 pandemic. As stated in Law Number 20 of 2003 concerning the National Education System, Government Regulation Number 17 of 2010 concerning Management and Implementation of Education, and Minister of Education and Culture Regulation 119 of 2014 concerning the Implementation of Distance Education at the Elementary and Secondary Education Levels. but this system is only an alternative which is an option for students and educational institutions to implement or not. ${ }^{4}$ The Ministry of Education and Culture (Kemendikbud) explained that the term PJJ was adopted from online learning. Online learning is a learning system that is not done face to face but uses a platform that connects teachers and students via the internet to be able to help the teaching and learning process that is carried out even though it is far away. The purpose of online learning is to provide quality learning services in a massive and open network. ${ }^{5}$

In an interview, some teachers at the school admitted that distance learning is less effective than face-to-face learning, for several reasons, one of which is. the limited ability of teachers to use technology in online learning. Not all teachers can operate computers or gadgets to support learning activities, both face-to-face, and even more so in distance learning. Indeed, some teachers can operate computers, but in terms of oppression, they are limited. They are not able to access further related to the internet network, use various learning applications, make their learning media/videos, and so on. Without a doubt, some teachers can master ICT as a whole. ${ }^{6}$

In practice as in Arabic learning, the distance learning system has given a new face. Learning, which usually uses a fairly high intensity, is now in a pandemic era, requiring educational institutions to make changes both from the system to learning styles. In its

\footnotetext{
${ }^{3}$ Luh Devi Herliandry et al., "Pembelajaran Pada Masa Pandemi Covid-19," JTP - Jurnal Teknologi Pendidikan 22, no. 1 (April 30, 2020): 65-70, https://doi.org/10.21009/jtp.v22i1.15286.

4 Belinda Gunawan, "Analisis Yuridis Pendidikan Jarak Jauh dalam Perspektif Hak Asasi Manusia dalam Undang-Undang Dasar NRI 1945 pada Masa Pandemi Covid-19 di Indonesia," Jurnal HAM 11, no. 3 (December 11, 2020): 387, https://doi.org/10.30641/ham.2020.11.387-404.

${ }^{5}$ Oktafia Ika Handarini, "Pembelajaran Daring Sebagai Upaya Study From Home (SFH)....." 8 (2020): 8.

6 Asmuni Asmuni, "Problematika Pembelajaran Daring di Masa Pandemi Covid-19 dan Solusi Pemecahannya," Jurnal Paedagogy 7, no. 4 (October 1, 2020): 281, https://doi.org/10.33394/jp.v7i4.2941.
} 
Nabella Sabella, Hasan : Arabic Teacher Creativity Towards The Use of Information Technology In Distance Learning

implementation, learning Arabic online encountered various obstacles. Both faced by students and teachers. Therefore, it is very necessary to maximize the use of technology to create innovations and future projections to answer these learning challenges so that they can contribute to learning, including a) being able to provide network-based learning information services; b) become a medium in a web-based learning model (online), c) become a medium in the implementation of elearning; d) become a medium in the education and distance learning system. ${ }^{7}$

Based on the description above, research was conducted for an overview regarding the creativity of Arabic language teachers in the use of information technology for distance learners during the COVID-19 pandemic. This is important to know how to implement and what obstacles and improvements are needed by the teaching staff in the field when the distance learning system regulations are enacted. With the hope of being able to provide information for improvements in policies that have been enacted.

Online learning is distance learning (PJJ). The distance learning system is a system that has been in use since the mid $18^{\text {th }}$ century. Since the first time the distance learning system was implemented, it cannot be separated from the use of technology in the implementation of learning, ranging from the simplest technology to the latest. In Indonesia, online learning is also referred to as 'network learning' or 'online learning. This is because online learning is a learning process whose interactions are carried out through the internet network. ${ }^{8}$

Meanwhile, the distance learning system (PJJ) contained in the circular letter of the Ministry of Education and Culture Number 15 of 2020, is a learning system that is implemented during the emergency period of spreading Corona Virus Disease (COVID-19). This learning system is a system that is implemented from within the home, using both an online (online) and offline (offline) approach. By using inclusive learning materials according to age and level of education, cultural context, character, and type of specificity of students. As for distance learning media and learning resources, through an online approach, you can use gadgets or laptops through several portals and online learning applications. As for the media and learning resources through the offline approach, it can be carried out through media such as Television, for example, is a learning program from home through TVRI. Or it could be through other learning media, such as. Radio, self-study modules and worksheets,

Because information technology is the most important part that can help the distance education process, information technology is not only a medium for information transfer and learning interaction in the implementation of distance learning. Furthermore, information and

7 Nanang Kosim et al., "PEMBELAJARAN BAHASA ARAB MELALUI DARING; PROBLEMATIKA, SOLUSI DAN HARAPAN,” 2020.

${ }^{8}$ Tian Belawati, Pembelajaran Online, 2nd ed. (Tanggerang Selatan: Universitas Terbuka, 2019).

Al Qalam: Jurnal Ilmiah Keagamaan dan Kemasyarakatan Vol. 16, No. 2 Maret - April 2022 
Nabella Sabella, Hasan : Arabic Teacher Creativity Towards The Use of Information Technology In Distance Learning

communication technology also acts as a tool used by teachers to continue to control learning, evaluate learning, pedagogical aspects, and eliminate learning problems that are separated by distance. (Abdul Latip 2020)

In practice, education in Indonesia uses a variety of learning media. Such as WhatsApp groups, telegram, google forms, google classroom, google meet or zoom to word wall games. The use of these media is generally adjusted to the teaching needs required by the teaching staff according to their ability to use information technology. The online learning media that have been mentioned are independent and high interactivity, able to increase memory levels, provide more learning experiences, with text, audio, video, and animation all of which are used to convey information, and also provide convenience in conveying, using content updates, downloads, students can also send messages to other students, post comments on discussion forums, use chat rooms, to video conference links to communicate directly. ${ }^{9}$

In addition to the media that have been mentioned, several startup companies are also involved in helping the distance learning process. Even these companies were already involved in the world of online learning before the pandemic. An example is one of the tech companies in Indonesia. Namely, Quipper provides free online learning systems and materials for teachers and students. where teachers can take advantage of Quipper's LMS (learning management system) feature to send and manage learning materials, exams, and student grades, enabling teachers to teach remotely. Furthermore, there is Ruangguru which develops various technology-based learning services, including virtual classroom services, online exam platforms, study videos, and other educational content that can be accessed through the web and the Ruangguru application. And finally, there is the Zenius learning application, which provides access to a practice question bank for student self-study materials. Teachers can also share content in the form of learning videos and practice questions to students and parents through various existing social media platforms, such as WhatsApp groups (Komalasari 2020)

In a pandemic situation like this, information technology is a major component in the learning process. Because in essence educational technology includes efforts that can be useful to create an effective and efficient learning process for each individual. This is in line with the latest definition of educational technology put forward by The Association of Educational Communication and Technology - the AECT - namely: educational technology can be defined as "...a study and ethical practice used to facilitate the ongoing learning process and improve performance through creation. appropriate use, project management, technology, and

\footnotetext{
9 Atsani Muhammad Zainuddin, "Transformasi Media Pembelajaran Pada Masa Pandemi Covid-19” 1 (2020).
}

Al Qalam: Jurnal Ilmiah Keagamaan dan Kemasyarakatan Vol. 16, No. 2

Maret - April 2022 
Nabella Sabella, Hasan : Arabic Teacher Creativity Towards The Use of Information Technology In Distance Learning

resources. ${ }^{10}$ From the definitions that have been mentioned, we can understand that although technology has an important role, it is only one component of education in modern times. The role of teaching staff as educators cannot be replaced by technology. The ability of the teaching staff to touch on aspects of taste, language, and character-building makes their presence something that is needed by students, anytime and anywhere. Technology plays a role in facilitating teaching staff in the learning process. The combination of the ability of teaching staff and technology is the right solution in learning in the era and especially after the pandemic. ${ }^{11}$

The development of 4.0-based technology has a very large impact in the world of education, including Arabic learning, which in practice is always undergoing a development process to adjust educational needs, especially when the distance learning system is implemented. ${ }^{12}$ Distance learning is a learning model that does not require students or students to come or attend school but can be carried out through remote communication by utilizing computer and/or internet technology such as email, electronic discussion forums, video conference using WhatsApp, Telegram, Google Meet applications., google classroom, zoom, and so on. ${ }^{13}$

In the distance learning system, information technology is one of the components to achieve learning success. The sophistication of learning facilities must be accompanied by adequate human resources so that technology can be utilized optimally properly and wisely. From the government, teachers, to parents each has a role in this. Both as a facilitator and controller. To utilize information technology in the learning process, several development steps can be taken, including the following: (1) designing and creating database applications, which store and process academic data and information, both learning systems, assessment systems, curriculum information, education management, as well as learning materials; (2) designing and creating portal-based learning applications, web, interactive multimedia, which consists of tutorial applications and learning tools; (3) optimizing the use of educational TV as enrichment material to support the improvement of the quality of education; and (4) implementing the system in stages

\footnotetext{
${ }^{10}$ Unik Hanifah Salsabila et al., "Peran Teknologi Dalam Pembelajaran Di Masa Pandemi Covid-19," Al-Mutharahah: Jurnal Penelitian dan Kajian Sosial Keagamaan 17, no. 2 (November 23, 2020): 188-98, https://doi.org/10.46781/al-mutharahah.v17i2.138.

11 Syaharuddin, "Menimbang Peran Teknologi Dan Guru Dalam Pembelajaran Di Era COVID-19," 2020.

12 Luluk Humairo Pimada and Muhammad Afif Amrulloh, "Penerapan Media Elektronik Pada Pembelajaran Bahasa Arab," Lahjah Arabiyah: Jurnal Bahasa Arab dan Pendidikan Bahasa Arab 1, no. 2 (July 14, 2020): 120-28, https://doi.org/10.35316/lahjah.v1i2.819.

${ }^{13}$ Ida Yeni Rahmawati and Dwiana Binti Yulianti, "Kreativitas guru dalam proses pembelajaran ditinjau dari penggunaan metode pembelajaran jarak jauh di tengah wabah COVID-19," n.d., 13.
}

Al Qalam: Jurnal Ilmiah Keagamaan dan Kemasyarakatan Vol. 16, No. 2 Maret - April 2022 
Nabella Sabella, Hasan : Arabic Teacher Creativity Towards The Use of Information Technology In Distance Learning

starting from a smaller scope to expanding, to facilitate the management of the use of IT in the process of providing education. ${ }^{14}$

As for some examples of learning media used during distance learning, as follows.

\section{Whatsapp and Telegram}

Whatsapp and Telegram are messaging applications for smartphones, WhatsApp and Telegram are cross-platform applications that help us exchange messages in the form of text, voice, photos, and videos. In addition, WhatsApp and Telegram also provide access in the form of regular calls to video calls. All these facilities can be enjoyed by using an internet data package. These two applications are generally used to create study groups for learning activities such as discussions and questions and answers. As well as for the provision of materials such as Maharaj istima', teachers can use voicemail access. In addition, the group chat feature in this application can help teachers train students' writing skills from communication that takes place via chat.

\section{Google Classroom}

Google Classroom is a free web service, developed to simplify, create, distribute, and grade assignments. Google Classroom Google Classroom is a mixed learning platform for the scope of education that can make it easier for teachers to create, share and classify each paperless assignment. ${ }^{15}$ This service is almost used in various subjects including Arabic. The service is very suitable to be used for the process of division of tasks and attendance.

\section{Google Forms}

Google form is a component of the Google Docs service. This application is very suitable for teaching staff to make quizzes, forms, and online surveys. Features of google forms can be shared publicly or specifically with google account owners with accessibility options, such as read-only (can only read) or editable (can edit documents). Thus, the google form is generally used as a learning medium for practice questions and final exams. ${ }^{16}$

\section{Google Meet}

14 farhania putri yusril, "Pemanfaatan Teknologi Informasi Dalam Bidang Pendidikan (E-education)," preprint (Open Science Framework, December 19, 2019), https://doi.org/10.31219/osf.io/ycfa2.

15 Roida Pakpahan and Yuni Fitriani, “Analisa Pemanfaatan Teknologi Informasi Dalam Pembelajaran Jarak Jauh Di Tengah Pandemi Virus Corona Covid-19” 4 (2020): 7.

16 Popi Radyuli, Rini Sefriani Sefriani, and Nurul Qomariah, "Pembelajaran Inquiry Menggunakan Google Form Terhadap Hasil Belajar Simulasi Dan Komunikasi Digital," EDUKATIF : JURNAL ILMU PENDIDIKAN 1, no. 2 (May 30, 2019): 56-63, https://doi.org/10.31004/edukatif.v1i2.6.

Al Qalam: Jurnal Ilmiah Keagamaan dan Kemasyarakatan Vol. 16, No. 2 Maret - April 2022 
Nabella Sabella, Hasan : Arabic Teacher Creativity Towards The Use of Information Technology In Distance Learning

Google Meet is a video communication service developed by Google. The platforms that can access Google Meet, among others. Android, iOS, and waring wera wanua. In addition, Google Meet also has a unique and functional interface that is lightweight and fast, prioritizes efficient management, has a share screen feature for presentation purposes, and is easy to use (user-friendly) that all participants can follow. ${ }^{17}$

\section{Zoom}

Zoom is a video calling app that was founded in 2011 in San Jose, California. The free version of Zoom cloud meeting can accommodate up to 100 participants. Similar to Google Meet, this application also provides a share screen feature. Zoom also provides a popular feature in the form of an image uploading service that is used as a background when conducting conferences. Both smartphones and PCs can easily access this application. With various features as well as the stability of video and audio, zoom is widely chosen in online-based learning activities.

Google Meet and Zoom applications with available features, these applications can be an option for teaching staff, especially when learning kalam, qiro'ah, and istima'. The interaction in the learning process through these two applications can be carried out more intensely. Both teachers and students will find it easier to express learning materials.

\section{Wordwall Games}

Wordwall game is a website-based application that can be used on any browser for free. This will greatly facilitate the teaching staff to create learning media such as quizzes, matchmaking, pairing, anagrams, word randomization, word search, grouping, etc. These features can be used to create optimal learning creations through this game, teaching staff can make varied practice questions. This website page is very suitable to be used for the mufradat learning process.

\section{RESEARCH METHODS}

This research uses field research and literature review methods. ${ }^{18}$. Data collection was obtained from the results of observations and interviews. The subject of this research is Ihya Ulumuddin Nur Sufiiyah Islamic Junior High School. This subject was selected using a purposive sampling technique, namely the selection of research subjects in a deliberate way by research based on certain criteria and considerations. Data analysis in this study using descriptive statistics is statistics used to analyze data by describing the data that has been collected as it is without intending to make conclusions that apply to the public or generalization. and according to

17 Dara Sawitri, "Penggunaan Google Meet Untuk Work From Home Di Era Pandemi Coronavirus Disease 2019 (Covid-19),” 2020, 9.

${ }^{18}$ Sugiyono, Metode Penelitian. Kuantitatif. Kualitatif, Dan R\&D (Bandung: Alfabeta, cv., 2016).

Al Qalam: Jurnal Ilmiah Keagamaan dan Kemasyarakatan Vol. 16, No. 2 Maret - April 2022 
Nabella Sabella, Hasan : Arabic Teacher Creativity Towards The Use of Information Technology In Distance Learning

Creswell this research belongs to the type of case study research. Namely, research that explores a particular case in greater depth by involving collectors of various sources of information. ${ }^{19}$ Based on its objectives, this research is included in applied research. That is research that aims to apply, test, and evaluate. To solve a problem ${ }^{20}$.

\section{RESULTS AND DISCUSSION}

\section{Utilization of information technology in the distance learning process in junior high school Islam Ihya Ulumuddin Nur Sufi'iyah}

In practice, regarding the use of technology that has been mentioned above, as a medium of learning as applied by SMP Islam Ihya Ulumuddin Nur Sufi'iyah. The school, which is located in Hulu Sungai Utara district, has been following the rules of the distance learning system, using Whatsapp and Google Classroom as learning media. The first is Google Classroom, this website service is used as the main learning medium. Play a role in the delivery of material, division of tasks, attendance and as a medium to create a discussion forum between students and teaching staff. For the delivery of Arabic language teaching staff at Islamic Junior High School Ihya Ulumuddin Nur Sufi'iyah Amuntai South of Kalimantan, they use social media to find educational content as a reference. After that, a learning video is made that is adjusted to the teaching materials that are applied at school as attractively as possible, then the video is uploaded and then the video link is shared in Google Classroom. Learning materials in the form of educational video content were chosen to create online learning classes that are not boring for students. After delivering the material through video content, the learning process continues with a discussion session between students and the teaching staff. Furthermore, there is Whatsapp, the Whatsapp application is used as a more intense communication medium for both students and guardians of students. Through WhatsApp, teachers approach students who are less active or have problems during the learning process. Other than that.

Learning through Google Classroom media encourages students to be able to maximize activity. Especially if students are given group assignments, from here students are expected to be able to build cooperative and collaborative learning groups even though in situations where they are in their respective homes, situations like this encourage students to be able to build good communication. In addition, on several occasions, students are given flexible study time, where students can develop independent study habits at their own pace and time. By encouraging student

19 J Raco R., Metode Penelitian Kualitatif. Jenis, Karakteristik, Dan Keunggulannya. (Jakarta: PT Gramedia Widiasarana Indonesia, 2010).

${ }^{20}$ Sugiyono, Metode Penelitian. Kuantitatif. Kualitatif, Dan R\&D.

Al Qalam: Jurnal Ilmiah Keagamaan dan Kemasyarakatan Vol. 16, No. 2 Maret - April 2022 
Nabella Sabella, Hasan : Arabic Teacher Creativity Towards The Use of Information Technology In Distance Learning

independence, it is hoped that students will be able to develop inquiry learning. In the middle of the distance learning system students are placed in a position where they are required to dig up more information independently. Therefore, The role of parents at home is very important. So that students get the right information at the right time to achieve the right goals. The use of information technology in educational services like this, not only improves the quality of student learning but also encourages collaboration that leads to thoughtful and creative interactions between teachers and parents in the process of student learning success. ${ }^{21}$

Arabic is a subject that learns a second language, most students think Arabic is a fairly difficult subject. Therefore, the creativity of the teacher greatly determines the attention of students. Because utilizing technology in the learning process not only motivates students but also improves their performance in the classroom. The choice of video content that is shared on Google Classroom services as a learning medium is not without reason, this is because studies have claimed that Arabic can be mastered more meaningfully if the instructor utilizes sounds, patterns, gestures, symbols, and multimedia blends in daily lessons. day. ${ }^{22}$ From a variety of video content, it is hoped that it can help students increase interest in learning Arabic. Google Classroom is also a place for learning interactions, where students and teachers often hold discussions both about learning materials and student learning tasks. Through the Google Classroom service, teachers who teach Arabic at the Islamic Junior High School Ihya Ulumuddin Nur Sufi'iyah find it very helpful to create a learning atmosphere that is quite attractive during a pandemic. And to anticipate boredom, teachers have a responsibility to present creative and up-todate learning content.

\section{The influence of teacher creativity on student learning motivation}

Understanding creativity can be viewed from four dimensions, namely person, process, product, and press. The person is defined by Sternberg as someone who can think synthetically. Munandar defines Process in creativity "Creativity is a process that manifests itself in fluency, inflexibility as well in the originality of thinking." That is, creativity is a process that is reflected in fluency, flexibility (flexibility), and originality in thinking. Next is the term product in creativity which is defined by Basuki as the ability to produce something new. And the last is the press or power that exists in the individual expressed by John Adlair "Creativity is the faculty of mind and spirit that enables us to bring into existence, ostensibly out of nothing, something of use, order, beauty or significance." This statement contains more or less the meaning, creativity is the

${ }^{21}$ Abdullahi Yusuf Usman, "Using Information And Communication Technology (Ict) To Enhance The Teaching And Learning Of Arabic And Islamic Studies In Nigeria,” n.d., 16.

22 Qais Faryadi, "Techniques of Teaching Arabic as a Foreign Language through Constructivist Paradigm: Malaysian Perspective," UiTM Malaysia, 2007.

Al Qalam: Jurnal Ilmiah Keagamaan dan Kemasyarakatan Vol. 16, No. 2 Maret - April 2022 
Nabella Sabella, Hasan : Arabic Teacher Creativity Towards The Use of Information Technology In Distance Learning

faculty of the mind and soul that enables us to bring into situations, as if out of nothing, something useful, order, beauty, or something meaningful. ${ }^{23}$

Teacher creativity cannot be separated from learning media. Media in the perspective of education is a very strategic instrument in determining the teaching and learning process. Because its existence can directly provide its dynamics to students. Media comes from the Latin "medium" which means an intermediary, while in Arabic the media comes from the word wassail which means an introduction to messages from the sender to the recipient of the message. ${ }^{24}$ The selection of the right media will help teachers maximize creativity in teaching and facilitate the process of delivering information and presenting material, while also creating a lively classroom atmosphere. Thus, it will be easier for students to understand each material.

The practical benefits of using learning media according to Arsyad are: a) clarifying the presentation of messages and information; b) enhance and direct attention; c) can overcome the limitations of the senses, space, and time; 4) provide common experiences to students about events in their environment. ${ }^{25}$

With the advancement of information technology, teaching staff in providing subject matter must follow these advances. Teaching staff must be able to use learning media that is interesting, fun, and by the learning needs of students. So that students can feel a pleasant learning atmosphere. By providing different learning experiences, can increase students' learning motivation because learning media can focus students' attention so that concentration on lessons increases. ${ }^{26}$ Learning motivation is the overall driving force or encouragement that comes from within and from outside a person who is learning to make changes in behavior to ensure the continuity of learning activities and provide direction to learning and learning objectives can be achieved. ${ }^{27}$ To get that, the teaching staff can display learning media that attract students' attention before learning begins.

\section{The need for equal distribution of the quality of education to increase creativity}

In an interview, some teachers in schools admitted that distance learning is less effective than face-to-face learning, for several reasons, one of which is the limited ability of teachers to

\footnotetext{
${ }^{23}$ R Mekar Ismayani, “Kreativitas Dalam Pembelajaran Literasi Teks Sastra,” n.d., 20.

${ }^{24}$ Wakhidati Nurrohmah Putri, "Pengaruh Media Pembelajaran Terhadap Motivasi Belajar Bahasa Arab Siswa Madrasah Tsanawiyah," LISANIA: Journal of Arabic Education and Literature 1, no. 1 (July 1, 2017): 1, https://doi.org/10.18326/lisania.v1i1.1-16.

25 Putri.

26 Teni Nurrita, "Pengembangan Media Pembelajaran Untuk Meningkatkan Hasil Belajar Siswa," MISYKAT: Jurnal Ilmu-ilmu Al-Quran, Hadist, Syari'ah dan Tarbiyah 3, no. 1 (June 27, 2018): 171, https://doi.org/10.33511/misykat.v3n1.171.

27 Putri, "Pengaruh Media Pembelajaran Terhadap Motivasi Belajar Bahasa Arab Siswa Madrasah Tsanawiyah."
}

Al Qalam: Jurnal Ilmiah Keagamaan dan Kemasyarakatan Vol. 16, No. 2

Maret - April 2022 
Nabella Sabella, Hasan : Arabic Teacher Creativity Towards The Use of Information Technology In Distance Learning

use technology in distance learning. Not all teaching staff can operate computers or gadgets to support learning activities, both face-to-face, and even more so in distance learning. ${ }^{28}$ This problem is increasingly having an impact on teaching staff in remote areas, apart from the lack of skills, the limitations of internet facilities and services are also very influential. Especially for those who have entered the senior category, the use of technology during learning activities presents its challenges.

In addition to the problems that have been mentioned. The fact is that the distance learning system has succeeded in showing a significant difference between the conditions of education in cities and villages, especially for villages that are quite far from the city center. The digital gap in distance learning can be seen from the survey results of The SMERU Research Institute (2020) that there are still $30 \%$ of teachers in rural areas outside Java who do not use digital applications in learning. There are even some teachers who are forced to visit their students because access to the internet is difficult and their budget is low. ${ }^{29}$

To overcome the challenges faced by some of the teaching staff in Indonesia, it is necessary to present government policies so that the implementation of equal distribution of education. It is hoped that there will be training in utilizing technology for teaching purposes. This is the main solution for teaching staff who fall into the category of technologically backward. In addition, the government must also pay attention to gadgets and internet facilities in educational environments in rural areas. Because to build a technology-based education ecosystem. To improve the competence of the teaching staff, it is appropriate to prepare a quality education and technology ecosystem. An educational ecosystem that is supported by technology is certainly very important to encourage the emergence of creativity, innovation, as well as a driving character for teaching staff. To create the ability to adapt to the winds of change. This stage requires creative power. Creativity will be able to bring people forward in an era that has changed. The era of the industrial revolution 4.0 also really needs creativity. ${ }^{30}$

\section{CONCLUSION}

Information technology is an important part that can help the distance education process, information technology becomes a medium for information transfer and learning interaction in the implementation of distance learning. In a pandemic situation like this, information technology becomes very important in the learning process. No exception in learning Arabic. Information

\footnotetext{
${ }^{28}$ Asmuni, "Problematika Pembelajaran Daring di Masa Pandemi Covid-19 dan Solusi Pemecahannya."

${ }^{29}$ Inas Mufidatul Insyiroh, Ela Puji Hariani, and Syahrul Mubaroq, "Pendidikan Berbasis Kearifan Lokal sebagai Solusi Menghadapi Kesenjangan Digital dalam Kebijakan Pembelajaran Jarak Jauh pada Masa Pandemi di Indonesia" 1, no. 1 (2020): 22.

${ }^{30}$ Meylan Saleh, "Merdeka Belajar di Tengah Pandemi Covid-19," n.d., 6.
}

Al Qalam: Jurnal Ilmiah Keagamaan dan Kemasyarakatan Vol. 16, No. 2 Maret - April 2022 
Nabella Sabella, Hasan : Arabic Teacher Creativity Towards The Use of Information Technology In Distance Learning

technology provides a variety of services that can be used as a medium of learning as well as a forum to increase the creativity of teaching staff to create an active and creative class. Even though in the middle of distance learning policy, it is hoped that this will not affect students' learning motivation. For this reason, the teaching staff is required to be able to make maximum use of information technology to achieve good learning outcomes. However, in practice, there are still many teaching staff who cannot use information technology properly and appropriately. This is influenced by several factors, such as. Those who are still included in the category of technology gaps, lack of gadget ownership, to the limited internet service. Therefore, it is hoped that there will be policies that can help improve the quality of human resources so that effective and efficient learning conditions are implemented by the distance learning system.

\section{REFERENCES}

Asmuni, Asmuni. "Problematika Pembelajaran Daring di Masa Pandemi Covid-19 dan Solusi Pemecahannya." Jurnal Paedagogy 7, no. 4 (October 1, 2020): 281. https://doi.org/10.33394/jp.v7i4.2941.

Belawati, Tian. Pembelajaran Online. 2nd ed. Tanggerang Selatan: Universitas Terbuka, 2019.

Faryadi, Qais. "Techniques of Teaching Arabic as a Foreign Language through Constructivist Paradigm: Malaysian Perspective.” UiTM Malaysia, 2007.

Gunawan, Belinda. "Analisis Yuridis Pendidikan Jarak Jauh dalam Perspektif Hak Asasi Manusia dalam Undang-Undang Dasar NRI 1945 pada Masa Pandemi Covid-19 di Indonesia." Jurnal HAM 11, no. 3 (December 11, 2020): 387. https://doi.org/10.30641/ham.2020.11.387-404.

Handarini, Oktafia Ika. "Pembelajaran Daring Sebagai Upaya Study From Home (SFH)...." 8 (2020): 8.

Hanifah Salsabila, Unik, Lailli Irna Sari, Khusna Haibati Lathif, Ayu Puji Lestari, and Asyharinur Ayuning. "Peran Teknologi Dalam Pembelajaran Di Masa Pandemi Covid-19." AlMutharahah: Jurnal Penelitian dan Kajian Sosial Keagamaan 17, no. 2 (November 23, 2020): 188-98. https://doi.org/10.46781/al-mutharahah.v17i2.138.

Herliandry, Luh Devi, Nurhasanah Nurhasanah, Maria Enjelina Suban, and Heru Kuswanto. "Pembelajaran Pada Masa Pandemi Covid-19." JTP - Jurnal Teknologi Pendidikan 22, no. 1 (April 30, 2020): 65-70. https://doi.org/10.21009/jtp.v22i1.15286.

Insyiroh, Inas Mufidatul, Ela Puji Hariani, and Syahrul Mubaroq. "Pendidikan Berbasis Kearifan Lokal sebagai Solusi Menghadapi Kesenjangan Digital dalam Kebijakan Pembelajaran Jarak Jauh pada Masa Pandemi di Indonesia" 1, no. 1 (2020): 22.

Ismayani, R Mekar. "Kreativitas Dalam Pembelajaran Literasi Teks Sastra," n.d., 20.

Kosim, Nanang, Imam Tarmudi, Novy Maryani, and Abdul Hadi. "Pembelajaran Bahasa Arab Melalui Daring; Problematika, Solusi Dan Harapan,” 2020.

Muhammad Zainuddin, Atsani. "Transformasi Media Pembelajaran Pada Masa Pandemi Covid$19 " 1(2020)$.

Al Qalam: Jurnal Ilmiah Keagamaan dan Kemasyarakatan Vol. 16, No. 2

Maret - April 2022 
Nabella Sabella, Hasan : Arabic Teacher Creativity Towards The Use of Information Technology In Distance Learning

Nurrita, Teni. "Pengembangan Media Pembelajaran Untuk Meningkatkan Hasil Belajar Siswa." MISYKAT: Jurnal Ilmu-ilmu Al-Quran, Hadist, Syari'ah dan Tarbiyah 3, no. 1 (June 27, 2018): 171. https://doi.org/10.33511/misykat.v3n1.171.

Pakpahan, Roida, and Yuni Fitriani. "Analisa Pemanfaatan Teknologi Informasi Dalam Pembelajaran Jarak Jauh Di Tengah Pandemi Virus Corona Covid-19" 4 (2020): 7.

Pimada, Luluk Humairo and Muhammad Afif Amrulloh. "Penerapan Media Elektronik Pada Pembelajaran Bahasa Arab." Lahjah Arabiyah: Jurnal Bahasa Arab dan Pendidikan Bahasa Arab 1, no. 2 (July 14, 2020): 120-28. https://doi.org/10.35316/lahjah.v1i2.819.

Putri, Wakhidati Nurrohmah. "Pengaruh Media Pembelajaran Terhadap Motivasi Belajar Bahasa Arab Siswa Madrasah Tsanawiyah." LISANIA: Journal of Arabic Education and Literature 1, no. 1 (July 1, 2017): 1. https://doi.org/10.18326/lisania.v1i1.1-16.

Raco, J, R. Metode Penelitian Kualitatif. Jenis, Karakteristik, Dan Keunggulannya. Jakarta: PT Gramedia Widiasarana Indonesia, 2010.

Radyuli, Popi, Rini Sefriani Sefriani, and Nurul Qomariah. "Pembelajaran Inquiry Menggunakan Google Form Terhadap Hasil Belajar Simulasi Dan Komunikasi Digital." EDUKATIF : JURNAL ILMU PENDIDIKAN 1, no. 2 (May 30, 2019): 56-63. https://doi.org/10.31004/edukatif.v1i2.6.

Rahmawati, Ida Yeni, and Dwiana Binti Yulianti. "Kreativitas guru dalam proses pembelajaran ditinjau dari penggunaan metode pembelajaran jarak jauh di tengah wabah COVID-19," n.d., 13 .

Saleh, Meylan. "Merdeka Belajar di Tengah Pandemi Covid-19," n.d., 6.

Sawitri, Dara. "Penggunaan Google Meet Untuk Work From Home Di Era Pandemi Coronavirus Disease 2019 (Covid-19)," 2020, 9.

Sugiyono. Metode Penelitian. Kuantitatif. Kualitatif, Dan R\&D. Bandung: Alfabeta, cv., 2016.

Susilo, Adityo, Cleopas Martin Rumende, Ceva Wicaksono Pitoyo, Widayat Djoko Santoso, Mira Yulianti, Herikurniawan Herikurniawan, Robert Sinto, et al. "Coronavirus Disease 2019: Tinjauan Literatur Terkini.” Jurnal Penyakit Dalam Indonesia 7, no. 1 (April 1, 2020): 45. https://doi.org/10.7454/jpdi.v7i1.415.

Syah, Rizqon H. "Dampak Covid-19 pada Pendidikan di Indonesia: Sekolah, Keterampilan, dan Proses Pembelajaran." SALAM: Jurnal Sosial dan Budaya Syar-i 7, no. 5 (April 14, 2020). https://doi.org/10.15408/sjsbs.v7i5.15314.

Syaharuddin. "Menimbang Peran Teknologi Dan Guru Dalam Pembelajaran Di Era COVID-19," 2020.

Usman, Abdullahi Yusuf. "Using Information And Communication Technology (Ict) To Enhance The Teaching And Learning Of Arabic And Islamic Studies In Nigeria," n.d., 16.

Yusril, farhania putri. "Pemanfaatan Teknologi Informasi Dalam Bidang Pendidikan (Eeducation)." Preprint. Open Science Framework, December 19, 2019. https://doi.org/10.31219/osf.io/ycfa2.

Al Qalam: Jurnal Ilmiah Keagamaan dan Kemasyarakatan Vol. 16, No. 2

Maret - April 2022 